\title{
Kerkbegrip van Balthasar Hubmaier
}

E T Endres ${ }^{1}$

(Universiteit van Pretoria)

\section{ABSTRACT}

\section{Balthasar Hubmaier's church concept}

Balthasar Hubmaier strives to restore the Urgemeinde as originally recorded in the book of Acts. He founded a congregation which consisted only of believers. The sacrament of baptism is exclusively intended for believers, as a confirmation of their belief in Jesus Christ. Believers are allowed to partake of Holy Communion as a supper/sacrament symbolizing remembrance and love. Hubmaier also introduced disciplinary measures to maintain Christian standards. Hubmaier moved through various phases of development, both as a human being and as a theologian. This development of Hubmaier is studied with particular reference to the Cognitive Dissonance Theory of Leon Festinger.

\section{AGTERGROND EN OPLEIDING}

Volgens die meeste navorsers is Hubmaier tussen 1480 en 1485 in Friedberg, naby Augsburg gebore. Hy matrikuleer op 1 Mei 1503. Daarna het hy aan die Universiteit van Freiburg in Breisgau as Baltesar Hiebmayr de Augusta ingeskryf. Hier het hy in die via moderna en die nominalisme opleiding ontvang. Hubmaier voltooi sy Baccalaureus-graad binne twee jaar en sy 'magistralen infulam' in 1507. Hy behaal sy doktorsgraad op 2 September 1512. Oor sy teologiese opleiding skryf Hubmaier later, 'er sei Doktor der Heiligen Schrift geworden, ohne die hauptsächlichsten christlichen Artikel verstanden, oder die Evangelien und Paulinischen Briefe zu Ende gelesen zu haben.' (Sachsse 1914:121)

\section{AS 'DOMPREDIGER' IN REGENSBURG}

Hubmaier het op 25 Januarie 1516 sy aanstelling as 'Domprediger' in Regensburg aanvaar. Sy verblyf in Regensburg is deur die antisemintiese stryd en deur die wonderwerke by die kapel, gekenmerk. Die Duitse bevolking in Regensburg het as gevolg van verskeie faktore mettertyd begin verarm. Die bevolking was egter oortuig dat

1 Artikel gebaseer op D.D.-proefskrif ingedien by die Dept. Kerkgeskiedenis aan die Universiteit van Pretoria in 2003. 
dit die skuld van Jode was dat hulle verarm het. Hulle het beweer dat hulle deur die Jode uitgebuit word en dat hulle te veel rente moes betaal. Die haat wat teenoor die Jode ontstaan het, het later tot godsdienstige fanatisisme oorgegaan. Daar is na die Jode as 'Christus-Mörder' verwys. Hubmaier was die woordvoerder van die anti-semitiese sentiment in Regensburg. Hubmaier het later die kerke in Regensburg, Ingolstadt en Friedberg om vergifnis gevra vir hierdie 'gottlosen Lehren...' (Sachsse 1914:127).

Die inwoners het in Februarie 1519 begin om die sinagoge af te breek. " $n$ Deel van die muur het op een van die bouers geval. Hulle het hom vir dood opgetel. Hy het egter later bygekom. Die inwoners was oortuig dat ' $n$ wonderwerk in hulle midde plaasgevind het en dat die dooie bouer deur Maria opgewek is. Hulle het op die plek waar die wonderwerk plaasgevind het, 'n kapel gebou met die naam, 'der schönen Maria'. Hubmaier het hier gepreek en die mense het na die kapel begin stroom. Georg Teschler, " $n$ monnik uit die Augustynse orde, skryf 'dass dieser zaubern könne'. (Bergsten 1961:86). Volgens Hubmaier het hier wonderwerke plaasgevind en hy het van die wonderwerke later begin aanteken. Een van die wonderwerke was dat van die mense in ' $n$ toestand van beswyming ingegaan en dan wild begin dans het en vreemde klanke gebruik het. 'n Mediese vriend het later vir Hubmaier gesê dat hy hiermee moet ophou. Van die mense wat hy ondersoek het, het na die ervaring van depressie begin kla. Hubmaier verlaat aan die einde van 1520 Regensburg en vertrek na Waldshut.

\section{HERVORMING IN WALDSHUT}

'n Eensame mens kom in Waldshut aan. Hy skryf aan sy vriend, Sapidus, dat hy baie eensaam is. In die tydperk onderneem hy ' $n$ reis en maak kontak met die belangrikste humaniste in Europa. Hy voer met Erasmus ' $n$ gesprek oor verskeie teologiese sake. Sapidus stuur vir hom literatuur oor Luther. Hy verdiep hom in die Pauliniese geskrifte. Later skryf hy dat hy diegene eer, wat 'an den Quellen der paulinischen Theologie trinken' (Westin en Bergsten 1962:14). Op 30 November 1522 keer hy vir " $n$ kort tydperk na Regensburg terug. Hier ontmoet hy die Lutheraan, Blaufärber Hans. Saam met hom en ander het hulle gereeld in sy huis bymekaar gekom vir studie en gebed. Hubmaier skryf later oor hierdie tydperk dat innerhalb zweier Jahre erst hat Christus angefangen in meinem Inneren $\mathrm{zu}$ grünen' (Westin en Bergsten 1962:19). Hubmaier keer op 1 Maart 1523 na Waldshut terug. 
Zwingli het in dieselfde tydperk met sy eie hervormings in Zürich begin. Hubmaier het sy begeerte uitgespreek om Zwingli te ontmoet. Op 1 Mei 1523 maak hy kontak met die leidende figure in Zürich. Hy het Zwingli ontmoet en hulle het oor verskeie sake gepraat. Die doop was een van die sake waaroor hulle gehandel het. Dit was tydens hierdie gesprek dat Hubmaier sy twyfel oor die kinderdoop uitgespreek het. Zwingli het op hierdie stadium ook getwyfel of kinders wel gedoop kan word. Hubmaier het saam met Zwingli aan die tweede Züricher Religionsgespräch van 26-28 Oktober 1523 deelgeneem. Tydens hierdie debat het hulle oor die Mis en die beelde in die kerk gepraat. Volgens die biskop van Konstans het Hubmaier langs Zwingli gesit en heelhartig met alles saamgestem wat Zwingli gesê het.

Hubmaier het met sy eie hervormings in Waldshut begin. Hy het die Mis vervang met ' $\mathrm{n}$ diens in Duits. Hy het ook die beelde uit die kerk verwyder. Hy het gewone dienste in Duits ingestel en het slegs uit die Bybel gepreek. Hy het mettertyd van alle katolieke gebruike ontslae geraak. Hy trou op 13 Januarie 1525 met Elsbeth Hügline von Reichenau.

Hubmaier se breek met Zwingli het egter vroeg in 1525 gekom. In Zürich was daar ondersteuners van Zwingli, Grebel, Reublin en Mantz, wat nie met Zwingli oor die tempo van hervorming saamgestem het nie. Zwingli was van mening dat die bevolking eers vir verandering voorberei moes word. Grebel, Reublin en sy ondersteuners het op radikale veranderinge aangedring. Hulle het ook gevoel dat die Stadsraad nie vir die hervorming verantwoordelik was nie en dat dit uitsluitlik ' $n$ geestelike aangeleentheid was. Verder het hulle oor die doop van kinders van mekaar verskil. Grebel en sy groep het reeds sedert 1524 hulle van die doop van kinders weerhou. Op 17 Januarie 1525 word 'n derde Züricher Gespräch gehou. Hierdie keer het dit oor die doop van kinders gehandel en was die gespreksgenote nie Katolieke nie, maar mede-hervormers wat onderlinge geskille gehad het. Die Stadsraad van Zürich het Zwingli en sy groep tot oorwinnaar verklaar en opdrag gegee dat Grebel en sy groep onmiddellik met die doop van kinders moet voortgaan. Grebel en sy groep weier en op 21 Januarie en 7 Februarie 1525 word heelwat volwassenes herdoop. Grebel, wat bewus was van Hubmaier se siening van die doop, vertrek na Waldshut waar hy Hubmaier probeer oortuig om hom te laat herdoop. Hubmaier weier egter. Reublin vertrek op Paasfees 
1525 na Waldshut. Hierdie keer was Waldshut gereed om herdoop te word. Hubmaier en sestig ander burgers is deur Reublin herdoop. Na hierdie geleentheid het hulle saam Nagmaal gevier wat met ' $n$ seremonie van voetwassing gepaard gegaan het. Die eerste Täufergemeinde is in April 1525 gestig.

\section{ANABAPTISTIESE GEMEENTE IN NIKOLSBURG}

Hubmaier vlug aan die einde van 1525 na Zürich. Hier word hy gevange geneem en onder marteling verhoor. Nadat hy onder dwang erken het, dat hy met sy standpunt oor die doop gedwaal het, word hy in April 1526 uit die tronk vrygelaat en vertrek hy na Nikolsburg. Hierdie het die laaste fase van die bediening van Hubmaier ingelei. Met die hulp van die invloedryke Von Liechtensteinfamilie begin hy onmiddellik met sy hervormingsprogram in Nikolsburg. Persone word as volwassenes gedoop. As gevolg van die godsdienstige toleransie het duisende mense na die stad gestroom. Volgens John Horsch het die gemeente binne een jaar tot twaalf duisend mense gegroei. Met die aankoms van ander denkrigtings vanuit die kringe van die Täuferbewegung ontstaan vinnig konflik binne die gemeente. Johannes Hus en sy volgelinge was teen die staat en die dra van die swaard gekant. Hulle was pasifisties-kommunisties geörienteerd. Ander weer het in sonde volhard, en het die skuld daarvoor aan God opgedra. Daar was ook verskillende sieninge van die Nagmaal. In die tydperk skryf Hubmaier verskeie geskrifte. Hierdie geskrifte was pastoraal en nie dogmaties van aard. Hy skryf twee geskrifte oor die staat en die dra van die swaard. Hy verwys na Hus en sy groep as bloedsuiers. Verder skryf hy twee geskrifte oor die vryheid van die wil. Hy skryf ook geskrifte oor die Nagmaal en die doop.

\section{DIE DOOD VAN HUBMAIER}

In Augustus 1527 skop koning Ferdinand alle vorme van toleransie op en word Hubmaier gevange geneem en na die kasteel in Oostenryk gebring. Hier ontvang hy opdrag om al sy standpunte te herroep. Die koning was egter nie met die herroeping van Hubmaier tevrede nie en hy sterf op 10 Maart 1528 op die brandstapel. Sy vrou word drie dae later in die rivier gegooi.

\section{KERKBEGRIP VAN HUBMAIER}

Al die standpunte van Hubmaier moet gesien word teen die agtergrond van sy Skrifbeskouing. Na sy bekeringservaring in die 
tydperk 1522/23, verwerp hy alle vorme van gesag en aanvaar hy die Bybel as die enigste Woord van God. Hy verwerp die spiritualistiese siening van die profete van Zwikau. Sy hermeneutiese sleutel was, 'the rule of Christ'. Alles wat deur Christus gebied word, moet uitgevoer word. Wat nie deur Hom gebied word nie, word implisiet verbied. Hy verskil ook van die verbondsbeskouing van Zwingli. Vanuit hierdie siening van die Skrif, word die kerkbegrip, siening van geloof, die sakramente, die siening van die owerheid, Christelike tug en die lewe binne die gemeente gebore. In sy siening van die kerk maak hy ' $n$ onderskeid tussen die kerk en die staat. Hy beweeg weg van die volkskerk-begrip en streef daarna om die Urgemeinde van Handelinge Twee te herstel. Hierdie gemeente bestaan slegs uit persone met ' $n$ persoonlike geloof in Jesus Christus en wat van hulle eie bekering en wedergeboorte kan getuig. In die opsig verwerp hy die tradisionele siening van geloof. Wanneer persone tot bekering gekom het, moet hulle gedoop word, soos deur die Nuwe Testament voorgeskryf. Die doop was 'n uiterlike getuienis van jou innerlike geloof. Omdat kinders nog nie in staat is om te glo, kan hulle ook nie gedoop word nie. Nadat gelowiges gedoop is, word hulle tot die Nagmaal as gedagtenis-, verbintenis- en liefdesmaaltyd toegelaat. Die sleutelmag lê by die gemeente wat namens Christus die mag het om te bind en te ontbind. Wie in sonde volhard, word uit die gemeente geban. Wanneer die sondaar egter berou toon, kan hulle tot die gemeente teruggelaat word. Volgens Hubmaier is die owerheid ' $n$ instelling van God en daarom mag hy die swaardmag uitoefen. Gelowiges word aangemoedig om belasting te betaal en mag wel poste in die owerheid beklee. In hierdie opsig verskil hy van die pasifistiese standpunt van ander wederdopers.

Die ideaal van Hubmaier was die herstel van die gemeente in Handelinge. In die praktyk het hy egter nie geslaag nie. Hubmaier het as ' $n$ eensame mens gesterwe, maar sy nagedagtenis het in vyfen-twintig geskrifte voortgeleef. Elke geskrif het hy geëindig met, 'die Warhayt ist vntodtlich'.

\section{DIE ONTWIKKELING VAN HUBMAIER ONDERSOEK IN DIE LIG VAN DIE KOGNITIEWE-DISSONANSIE TEORIE VAN LEON FESTINGER}

Hubmaier se ontwikkeling as mens en teoloog het deur verskillende fases beweeg, naamlik Katoliek, Lutheraan, Zwingliaan en Anabaptis. Die mees opvallende was dat hy en sy vriende in Zürich oor die meeste sake saamgestem het. Later het hulle egter die 
grootste vyande geword. Die tydperk waarin Hubmaier, Zwingli, Luther en ander reformatore geleef het, was die reformasie nog in 'n onafgeronde proses. Standpunte oor geloof, die Bybel, die kerk, die Nagmaal, die doop, tug en baie ander sake moes nuut geformuleer word. Die eindresultaat was egter dat vriende so radikaal van mekaar verskil het dat verskillende strominge binne die reformasie tot stand gekom het. Later wou hulle nie eers meer met mekaar praat nie. $\mathrm{Na}$ die dood van Hubmaier, skryf Faber oor die standpunte van Hubmaier, "the writing contained statements which surprised John Faber, who found it strange that a person with so little doctrinal difference would separate from the Roman Church. It may reflect the general problem of the breakdown of communication and realtionships between the central figures of the Reformation and the Counter-Reformation: there were very few who really listened to the others' (Liland 1983:85).

In my navorsing het ek ook aandag gegee aan die psigologiese ontwikkeling van Hubmaier. Dit het ek gedoen aan die hand van die kognitiewe-dissonansie teorie van Festinger. Hierdie teorie ondersoek 'attitude-discrepant behavior' en handel dus oor die houding (attitude) en die gedrag (behavior) van mense.

Volgens Festinger beleef ' $n$
mens ' $n$ vorm van ongemak (dissonansie) wanneer hy agterkom dat hy/sy [a] twee of meer houdings het oor ' $\mathrm{n}$ saak of [b] wanneer sy/haar houding en gedrag in stryd met mekaar is. Kognitiewe dissonansie word

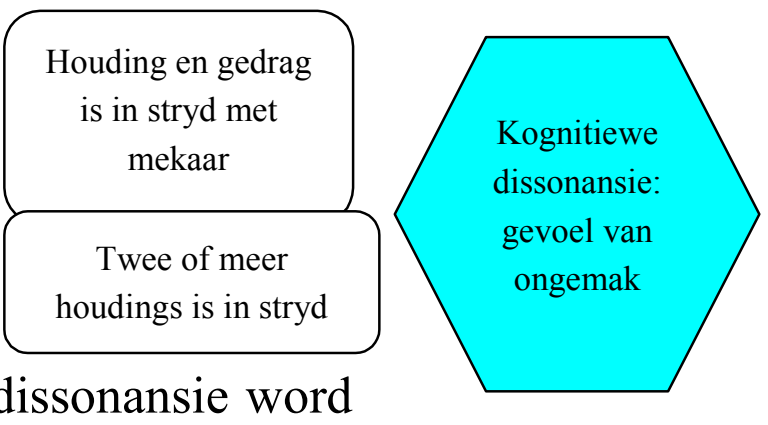
dus omskryf as 'an unpleasant state that occurs when we notice that various attitudes we hold, or our attitudes and our behavior are somehow inconsistent' (Baron Byrne: 1996:138). In hierdie definisie vervang Festinger die woord 'inconsistency' met 'dissonance' en die woord 'consistency' met 'consonance' (Festinger 1957:2).

Die woord 'attitude' word in hierdie artikel met die woord 'houding' vertaal. Volgens Abraham Tesser is die onderbou van ' $n$ individu se houding 'beliefs, emotions and behavior', (Tesser 1995:198) en 'attitudes are organized into affective, cognitive, and behavioral subsystems' (Tesser 1995:200). In enige vorm van aanpassing of verandering moet ' $n$ individu of sosiale gemeenskap se sentiment (die affektiewe), denke (die kognitiewe) en oortuigings (geloofsoortuigings) oor sake aangespreek word. Wanneer een van 
dié aspekte nie aangeraak of verreken word in ' $n$ poging om dissonansie te verminder nie, vind daar geen permanente verligting van dissonansie plaas nie.

Wanneer kognitiewe dissonansie sterk genoeg beleef word, dien dit as motiveringsfaktor om van die oorsake ontslae te raak of selfs net te verminder, om weer konsonansie te herstel. Kognitiewe dissonansie sit " $n$ proses aan die gang wat tot verandering lei. Volgens Festinger is daar ses hanteringsmeganismes wat gebruik kan word om konsonansie te herstel: [a] pas houding by gedrag aan; [b] pas gedrag by houding aan; [c] verkry nuwe kognisie; [d] trivialisering; [e] rasionalisering; [f] verander verklaringsbeginsel: hermeneutiese sleutel; [g] Resultaat van die hele proses: vorming van ' $n$ nuwe sosiale struktuur waarin verandering as geloofwaardig en betroubaar gevalideer word. Skematies kan dit so voorgestel word: 


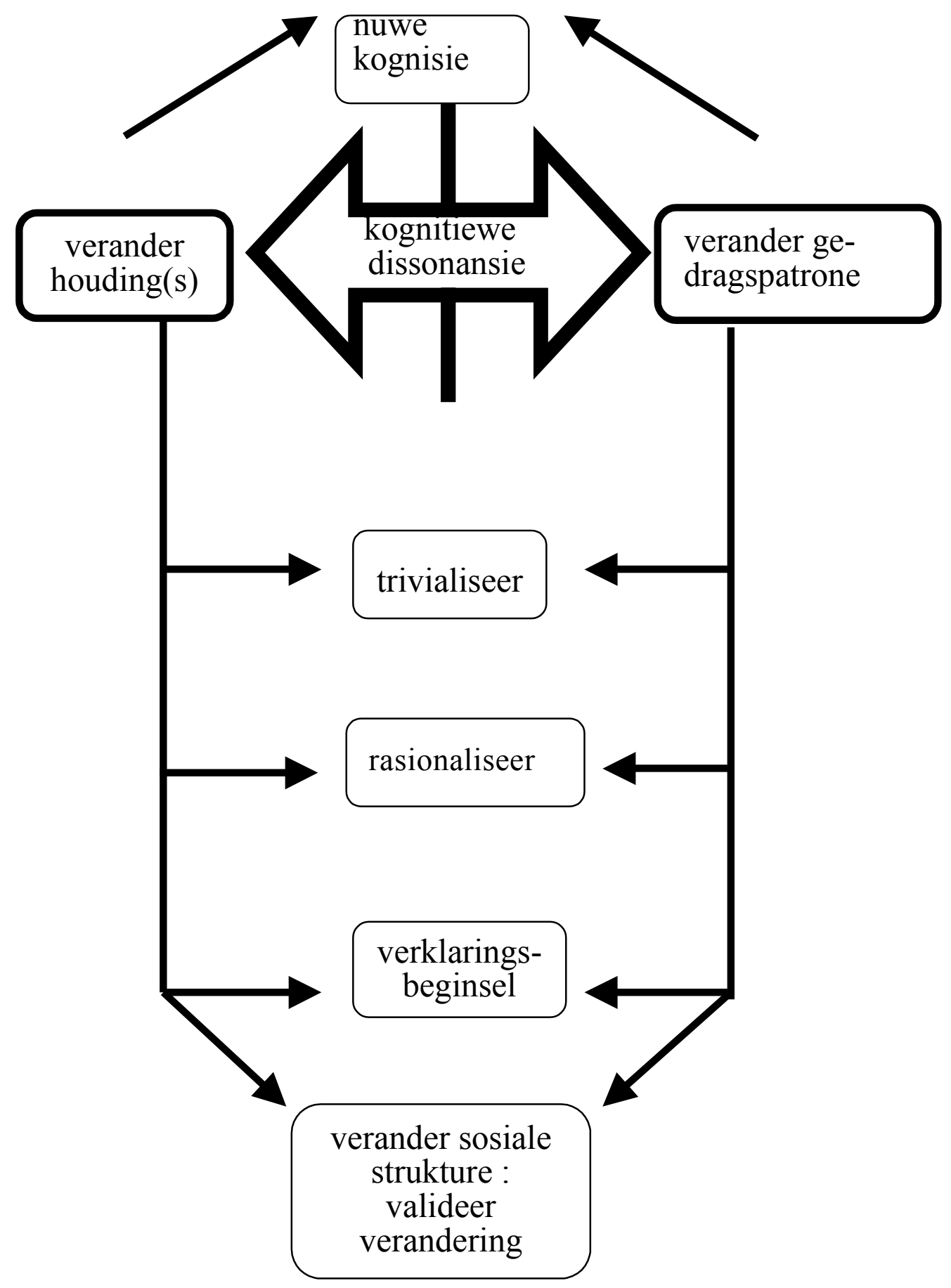

\subsection{Kognitiewe dissonansie binne Katolieke kringe}

\subsubsection{Hubmaier se belewenis van kognitiewe dissonansie}

Nadat Hubmaier Regensburg verlaat het, vertrek hy na Waldshut. Verskeie redes word vir die vertrek vir Hubmaier aangevoer. Sachsse beweer dat dit oor sy hantering van die Joodse vraagstuk gegaan het. Ander beweer dat dit oor verskille tussen die Stadsraad en die geestelike leiers oor die hantering van geldsake gegaan het. 
Verder is gespekuleer dat dit oor bevorderingsmoontlikhede gegaan het. Die aanvanklike redes was egter nie leerstellig van aard of dat hy vir sy lewe moes vlug nie. In 'n brief skryf hy dat hy oor die uitbreek van pes gevlug het. Dit is egter ook so dat nie baie mense oor die uitbreek van pes uit Regensburg gevlug het nie. Die belangrikste is dat hy Regensburg verlaat het. Dit word later uit sy geskrifte duidelik dat hy ' $n$ innerlike leegheid in dié tydperk begin beleef het. Hy skryf in Oktober 1521 aan Sapidius oor sy eensaamheid en dat hy graag met die vooraanstaande humaniste in aanraking wil kom. In hierdie brief kry ons die eerste tekens dat Hubmaier ongemak (kognitiewe dissonansie) beleef. Hy was op daardie stadium in ' $n$ tweestryd gewikkel. Hierdie gevoel van ongemak het as motivering gedien om van oorsake van sy ongemak, soos hieronder verduidelik word, ontslae te raak.

\subsubsection{Nuwe kognisie}

Tydens Hubmaier se ervaring van kognitiewe dissonansie besluit hy om in 1522 ' $n$ navorsingsreis te onderneem en met die belangrikste humaniste in verbinding te tree. Hy tree in gesprek met invloedryke meningsvormers soos Erasmus en Glarean. Met Erasmus voer hy gesprekke oor belangrike geloofsake. Miskien het hy verwag dat Erasmus sommige van sy standpunte sou bevestig, maar die teendeel gebeur: Erasmus het sy gevoel van dissonansie verhoog deur van sommige Katolieke standpunte af te wyk.

Hubmaier het egter besluit om nog inligting in te win. Hy verdiep hom in die klassieke literatuur en lees ook parafrases van Erasmus oor die Pauliniese geskrifte. Hy verdiep hom ook in die Bybel en maak ' $n$ studie van die evangelies en die Pauliniese geskrifte. Hy lees die kommentare van Luther oor Romeine en Korinthiërs. Hy versoek Adelphius om hom die kommentaar oor Filippense te stuur. Verder lees hy ook die geskrif van Luther oor die Nagmaal.

\subsection{3 ' $n$ Verandering in die houding van Hubmaier vind plaas}

In die jare 1521 tot 1522 begin die eerste tekens van verandering in die houding van Hubmaier duidelik word. Volgens Festinger pas persone eers hulle houding aan, voordat hulle hul gedrag by hulle houding aanpas. Hy skryf aan Sapidius dat hy diegene eer wat aan die Pauliniese bron drink. Hy verwys met behae in 1522 in ' $n$ brief aan Adelpius na die kloosters wat leegloop en dat priesters en nonne met mekaar trou. In ' $n$ brief aan W Rychard skryf hy dat hy diegene 
eer wat Christus verkondig en wat die Evangelie preek. Daar begin 'n klemverskuiwing in die houding van Hubmaier plaasvind. Hy het anders oor Katolieke standpunte soos dié oor geloof, gesag, die Woord, sakramente, kloosters, monnikke en nonne begin dink. Nadat Hubmaier nuwe inligting (kognisie) versamel het, begin hy om sy geloofsoortuigings, gevoelens en denke oor sekere Katolieke standpunte te verander. Dit het veral in sy briefwisseling duidelik geword. In sy optrede (gedrag) bly hy egter nog steeds getrou aan Katolieke gebruike. Veral in die eerste deel van sy verblyf in Waldshut handhaaf hy steeds al die Katolieke gebruike. Volgens Sachsse was die optrede van Hubmaier op hierdie stadium nie Lutheraans of Reformatories nie, maar wel 'reaktionär-katholisch'. Hy het nog nie tot die verbreking van sy bande met die Katolieke Kerk oorgegaan nie.

Gedurende sy verblyf in Waldshut word hy ' $n$ tweede keer na Regensburg beroep. Die verskuiwing in die houding van Hubmaier was nog nie sigbaar en ook nog nie bekend nie. Hy aanvaar die beroep en keer vir " $n$ rukkie na Regensburg terug. Gedurende sy tweede verblyf maak hy kontak met Blabhans, "n Lutheraan. In latere geskrifte verwys Hubmaier daarna dat Christus in hierdié periode vir hom ' $n$ werklikheid geword het. Die proses van verandering in die houding van Hubmaier, wat in Oktober 1521 begin het, is met sy bekering in 1522 voltooi. Bekering het juis, onder andere, met ' $\mathrm{n}$ houdingsverandering te doen.

\subsubsection{Verandering in die gedrag van Hubmaier}

Hubmaier keer op 1 Maart 1523 met nuwe visie, energie en planne na Waldshut terug. Hy begin om sy hervormingsprogram versigtig deur te voer. Hy fokus eerstens op die houding (affektiewe; persoonlike oortuigings; kognitiewe fasette) van die bevolking, voordat hy tot hervorming oorgaan. In sy prediking rig hy hom tot die bevolking en sê dat die Woord van God suiwer verkondig moet word. Hy wil hulle na die enigste bron van gesag, wat hy ook aanvaar het, terugbring. Die gesag van die pous, die besluite van konsilies en die prediking van die priesters moet in die lig van die Woord geëvalueer word. Die eerste saad van twyfel word gesaai en die eerste vorm van kognitiewe dissonansie kom onder die bevolking van Waldshut tot stand. Die bevolking hoor dat die Woord meer gesag as die pous het en dat hulle meer krities na hulle priesters moes luister. 
Daarna wend Hubmaier hom tot die geleerdes in Waldshut. Hy daag die ander Katolieke priesters tot 'n gesprek uit. Met die oog hierop berei hy ' $\mathrm{n}$ gespreksdokument voor. Ook in die houding van die ander geestelike leiers in Waldshut word die saad van twyfel gesaai. Mettertyd sou ook hulle hulle eie vorme van dissonansie verwerk deur deel van die hervorming te word of deur by hulle oortuigings as Katolieke te bly.

Hubmaier beweeg egter " $n$ tree verder deur die guns van die Stadsraad van Waldshut te wen. Hy word hulle politieke raadgewer. Mettertyd het die Stadsraad in ' $n$ stryd met die huis van Habsburg gewikkel geraak. Hy en die Burgermeester word groot vriende. Die boereopstande sou egter ' $n$ ander vorm van dissonasie veroorsaak. Waldshut, wat deel van die boeregemeenskap was, het nie ' $n$ ander keuse as om die kant van die boere in die suide van Duitsland te kies nie. Kognitiewe dissonasie het dus nie net op godsdienstige gebied plaasgevind nie. Ook op politieke gebied ontstaan kognitiewe dissonansie. Keuses moes gemaak word om oortuigings en optrede in harmonie met mekaar te kry. Die invloed van Hubmaier op die bevolking en die politieke en geestelike leiers begin vrugte afwerp. Die boeregemeenskap in Waldshut was gereed vir hervorming.

Hy sou egter met nog ander belangrike meningsvormers in Katolieke kringe in gesprek tree. Dié optrede van Hubmaier is gereeld aan die biskop van Konstans en die huis van Habsburg gerapporteer. Hy tree in gesprek met Johannes Faber (Waldshut het onder sy beheer geval) en met die leidende akademikus, Johannes Eck. Hy verduidelik sy optrede en probeer om homself op hierdie wyse te regverdig. Dit was tog belangrik dat hy ook hulle goedgesindheid sou behou. Dit het egter nie plaasgevind nie. Die twee figure sou hulle later van Hubmaier distansieer.

\subsubsection{Eindresultaat: 'n nuwe geloofsgemeenskap kom tot stand}

Hubmaier het aanvanklik geringe vorme van hervorming deurgevoer. Hy het sy tevredenheid met die veranderinge wat op ander plekke plaasgevind het, uitgespreek. Hy praat met groot tevredenheid van die kloosters wat oop is en dat priesters en nonne met mekaar kon trou. Hy het stelselmatig begin om hervormings deur te voer. Die mis is vir die eerste keer in Duits gevier. Hy het in Duits begin preek. Mettertyd is sekere voorwerpe uit die kerkgebou verwyder. Met die doop van volwassenes en die viering van die Nagmaal in April 1525 word die Gemeente in Waldshut vir die 
Reformasie gewen. ' $n$ Nuwe geloofsgemeenskap het in Waldshut tot stand gekom.

\subsection{Kognitiewe dissonansie binne Reformatoriese kringe}

\subsubsection{Kognitiewe dissonansie: die praktyk van die Hervorming}

Die hervormingswerk in Zürich en Waldshut was nou verbind. In Oktober 1523 tydens die tweede gesprek in Zürich het leiersfigure soos Zwingli, Reublin en Hubmaier oor die beginsel van hervorming saamgestem. Tydens hierdie gesprek was hulle dit eens oor die gesag van die Skrif en 'n paar ander sake. Na hierdie gesprek het daar ' $n$ geskil oor die proses van die hervorming ontstaan. Binne die kring van die Hervormers het daar 'n nuwe vorm van kognitiewe dissonansie ontstaan. Hierdie het nie meer oor die Katolieke Kerk gegaan nie, maar oor die pas van hervorming, hoe ver die hervorming deurgevoer moet word, die verhouding tussen die staat en kerk en die sakramente. Hubmaier het die woordvoerder van diegene geword wat op ' $n$ radikale vorm van hervorming aangedring het.

\subsubsection{Hermeneutiese vraagstuk}

Die gespreksgenote was nie meer Katolieke nie, maar wel medeReformatore met klemverskille. In die gesprekke met die Katolieke is daar oor die Woord as die enigste bron van gesag besin. Die Reformatore het die Skrif as die enigste bron van gesag aanvaar. In die gesprek met mede-Reformatore gaan dit nie meer oor 'sola scriptura' nie, maar wel oor hoe die Skrif uitgelê moet word. Die geskil het oor ' $n$ hermeneutiese vraagstuk gehandel. Die Reformatore in Zürich het sowel die Ou Testament, as die Nuwe Testament as die Woord van God aanvaar. Die verbondsgedagte het baie sterk by hulle begin funksioneer. Dit het Zwingli se siening van die kerk as verbondsgemeenskap en sy siening van die sakramente as verbondstekens bepaal. Die kerk is ' $n$ volkskerk en alle verbondskinders moet gedoop word.

Hubmaier het ' $\mathrm{n}$ ander hermeneutiese sleutel gebruik, naamlik die reël van Christus. Slegs die opdragte van Christus moet uitgevoer word. Die saad van dissonansie is in die midde van die Reformatoriese kringe gesaai. Hulle het die Bybel verskillend gelees en uitgelê. Vir Hubmaier het dit duidelik geword dat ' $n$ gemeente slegs uit gelowiges, wat die belydenis-doop ontvang het, kon 
bestaan. Hy het gevoel dat die opdragte van Christus tot sy volle konsekwensies deurgevoer moet word.

\subsubsection{Insamel van inligting (nuwe kognisie)}

Hubmaier tree met die belangrike persone in Zürich oor die doop in gesprek. Uit die korrespondensie blyk dit dat daar geen duidelikheid oor die doop bestaan het nie. Hubmaier was oortuig dat die doop slegs as teken van geloof bedien mag word. Hy het sy standpunt aanvanklik nie openbaar gemaak nie. In Januarie 1525 vind ' $n$ volgende gesprek in Zürich plaas. Hierdie gesprek vind plaas tussen persone wat oor die beginsel van hervorming saamgestem het, maar oor die tempo daarvan verskil het. In die kern van die gesprek het die siening oor die doop gestaan. Weereens word Zwingli deur die Stadsraad van Zürich tot oorwinnaar verklaar. Op 21 Januarie 1525 word die eerste volwassenes in Zürich gedoop. Hubmaier moes ' $n$ keuse makk. Die skeuring onder die Hervormers was finaal. 'n Nuwe beweging onder die Hervormers was in wording. Hubmaier was oortuig van die doop van volwassenes. Hy wou hom egter nie van sy vriende in Zürich vervreem nie. Hy wou nog steeds sy gesprekke met hulle oor die doop voortsit, maar daar het niks van gekom nie. Lede van die Täuferbewegung in Zürich vlug na Waldshut. Hulle plaas groot druk op Hubmaier om tot die praktyk van die belydenisdoop oor te gaan.

In April 1525 word Hubmaier en ander lede van sy Gemeente in Waldshut gedoop. Behalwe dat Hubmaier tot die hervorming oorgegaan het, het hy een stap verder gegaan. Hy het volgens sy oortuigings die volle pad van die 'reël van Christus' bewandel. Die kerk bestaan uit gelowiges wat deur die doop in die openbaar van hulle geloof getuig. Daarmee het daar onder die Hervormers skeuring gekom. Daarna is dit nie net die Katolieke Kerk en die huis van Habsburg wat hulle van die gebeure in Waldshut distansieer nie. Ook Hubmaier se vriende in Zürich word sy aartsvyande.

In Waldshut het daar ' $\mathrm{n}$ nuwe gemeenskap tot stand gekom. Alle eendersdenkendes vlug na Waldshut. Met die inval van die soldate van die huis van Habsburg vlug Hubmaier na Zürich met die vermoede dat hy " $n$ vriendelike ontvangs sou kry. Hy word egter summier gevang en in die tronk gegooi. 


\subsubsection{Rasionalisering}

Festinger sê 'once individuals choose their form of dissonance reduction, they tend to ignore all others. In short, not only do we choose the path of reduction; once we head down it, we don't bother to glance, cognitively, at the alternatives' (Baron en Byrne 1997:142). Nadat Hubmaier uit die tronk vrygelaat is, vertrek hy na Augsburg en Nikolsburg. In Augsburg was ' $n$ groot biblioteek en hy begin met 'n geskrif oor die doop van volwassenes. Hy haal kerkvaders, humaniste, Reformatore en tydgenote aan. Uit al die aanhalings wil hy aantoon dat die doop van volwassenes deur die eeue toegepas is. Hy haal Luther se siening oor die doop van volwassenes aan. Hy verwys na die persoonlike stryd wat Zwingli oor die doop van kinders gehad het en dat hy saamgestem het dat kinders nie gedoop mag word nie.

Die meeste van hierdie aanhalings was egter onakkuraat. Hubmaier het reeds besluit dat die doop van volwassenes die enigste ware doop is, en hy het alles verdraai om by sy sienswyse aan te pas. Sowel Luther as Zwingli, het later ontken dat hulle ooit voorstanders van die doop van volwassenes was. ' $n$ Katolieke navorser het later aangetoon dat die aanhalings van Hubmaier van kerkvaders en die besluite van die konsilies nie korrek was nie. Hubmaier wou met 'alle geweld' almal oortuig dat sy standpunt nie net Bybels is nie, maar nog altyd die gebruik van die kerk was.

\subsubsection{Werwing van volgelinge wat houding en gedrag ondersteun}

Sover as wat Hubmaier beweeg het, het hy nuwe ondersteuners vir sy siening oor die doop verwerf. In Nikolsburg stig hy sy tweede Täufer-gemeinde. Hy tree weereens in gesprek met al die geestelike leiers in Morawië. Hy praat met soveel oortuiging dat hulle hom volg. Hy rig hom ook tot die stadsvaders en hulle word vir die Täuferbewegung gewen. In sy geskrifte rig hy hom tot die invloedrykste adellikes in Morawië en Bohemië. Hy maak van ' $n$ drukker gebruik om sy geskrifte te versprei. Nikolsburg word ' $n$ veilige hawe vir alle andersdenkes in die Duitssprekende wêreld. ' $n$ Nuwe gemeenskap met unieke gebruike het inderdaad tot stand gekom.

\subsubsection{Samevattend}

Gereformeerde gelowiges het saamgestem oor die beginsel van hervorming, maar ongelukkig het hulle verskil oor die metode. Die 
geskil wat tussen die twee groepe ontstaan het, het oor ' $n$ hermeneutiese vraagstuk gegaan. Daaruit is verskillende kerkbegrippe en sienings oor die doop en die funksionering van die Christelike gemeenskap gebore.

\subsection{Kognitiewe dissonansie binne die Täuferbewegung}

\subsubsection{Oorsake van kognitiewe dissonansie}

Die eerste Täufergemeente is in April 1525 in Waldshut gekonstitueer. Hulle het 'n eenvoudige aard gehad: 'n gemeente wat uit gelowiges bestaan en wat hulle groot laat doop het. Die eerste saad van kognitiewe dissonansie sou egter kort daarna in die gemeente gesaai word. Dit het oor die siening van die swaard gegaan. Daar was gelowiges wat geglo dat die eise van Christus tot op die letter toegepas moes word. Die Bybel vereis dat jy jou vyande moet liefhê (Matteus 5:43-48) Op grond van hierdie 'reël van Christus' het sommige in Waldshut geglo dat ' $\mathrm{n}$ gelowige nie die swaard mag dra en ook nie deel aan die owerheid mag hê nie. Gelowiges mag nie in dieselfde juk as ongelowiges trek nie. Onder die lede van die Täufergemeente in Waldshut het daar twee groepe ontstaan, die 'stäpler' en die 'schwertler'. Hubmaier het geglo dat gelowiges die swaard mag dra. Met die dreigende aanval van die huis van Habsburg moes almal hulle bydrae lewer om die stad te verdedig. Hubmaier gee nie veel aandag aan hierdie vraagstuk nie. Die persone wat nie die swaard wou dra nie, word uit die stad gejaag en as bloedsuiers bestempel. Die standpunt oor die swaard sou egter later ' $\mathrm{n}$ groot twispunt in die Täuferbewegung word en sou tot skeuring aanleiding gee.

Hubmaier se tweede gemeente in Nikolsburg groei baie vinnig. Hulle word oorval deur vlugtelinge wat almal beskerming in Nikolsburg wou vind. Mettertyd word mense voor die voet gedoop en tot die gemeente toegelaat. Die vinnig groeiende gemeente het met nuwe probleme gesit. Die integriteit van die gemeente en dat die gemeente slegs uit gelowiges mag bestaan, word bedreig. Die handeling van die doop word belangriker as onderrig en ondersoek na ware geloof. Mettertyd word kritiek van binne uitgespreek. Hubmaier moes met nuwe gebruike, die Christelike opvoeding, onderlinge vermaning en die Christelike ban, begin.

Met die vinnig groeiende gemeente kom ander leiers met ander sienswyses na die gemeente. Een van hulle was Hans Hut wat sterk standpunte oor die dra van die swaard, die owerheid en die 
wederkoms gehad het. Die vrede in die gemeente word versteur. ' $n$ Gesprek tussen Hubmaier en Hut word gereël. Die ondersteuners van Hubmaier gryp Hut en gooi hom in die tronk. Hierop het die ondersteuners van Hut sterk gereageer en Hut en sy vriende word die volgende dag vrygelaat.

\subsubsection{Nuwe sosiale strukture neem vorm rondom verskillende oortuigings aan}

Soos in Waldshut, skeur ook hier ' $\mathrm{n}$ gemeenskap in twee. Hierdie keer het dit oor die siening oor die swaard onder die lede van die Täuferbewegung gegaan. Die 'stäpler' was in die meerderheid en Hubmaier verloor baie aanhang. Die interne probleme wat in Waldshut ontstaan het, het sy klimaks in Nikolsburg bereik. Hubmaier wou nog steeds sowel die guns van die adellikes, as die guns van koning Ferdinand, behou. Terwyl Hubmaier in die tronk in Wene was, verdedig hy sy siening van die swaard en onderwerp hy hom ook aan die gesag van koning Ferdinand. Dit was egter alles tevergeefs. Hy sterf as ' $n$ eensame mens op die brandstapel. Hubmaier het geen vriende meer gehad nie. Die Katolieke, die Hervormers en die ander lede van die Täuferbewegung het hulle van Hubmaier gedistansieer.

\subsubsection{Samevattend}

Die Täuferbewegung het in hulle siening oor die kerk en die doop saamgestem, en tog vind daar weer interne skeuring plaas en word daar onder die wederdopers verskillende groepe gevorm wat verskillende vorme van spiritualiteit verteenwoordig. Kognitiewe dissonansie is ' $n$ gegewe in elke struktuur. Die wyse waarop dit bestuur word, bepaal die kenmerke van die eindproduk!

\section{RELEVANSIE VAN DIE KOGNITIEWE-DISSONANSIE TEORIE VIR DIE KERK}

Kennis van kognitiewe dissonansie en hoe mense daarop reageer kan as bestuurs-, verklarings- en voorspellingsmodelle ook vir die kerk aangewend word. [a] Dit kan aangewend word om te voorspel hoe sekere prosesse van verandering moontlik kan plaasvind. Alle aspekte van die houding (emotiewe, kognitiewe; oortuigings) en gedrag van mense moet in gedagte gehou word om enige proses van verandering sinvol te bestuur. [b] Dit kan ook as " $n$ verklaringsmodel gebruik word om aan te dui waar sekere prosesse verkeerd geloop het. [c] Belangriker nog, dit kan as ' $n$ 
bestuursmodel gebruik word om sekere slaggate te vermy en om ' $n$ program saam te stel om veranderinge wat op hande is só te bestuur dat die meerderheid van mense daarmee saam geneem kan word.

\section{Literatuurverwysings}

\section{Primêre Bronne}

Balthasar Hubmaier Schriften. Edited by Gunnar Westin and Torsten Bergsten. Gütersloh, Germany: Gütersloher Verlagshaus Gerd Mohn, 1962:

-, Achtzehn Schlußreden. Balthasar Hubmaier Schriften. Edited by Gunnar Westin and Torsten Bergsten. Gütersloh, Germany: Gütersloher Verlagshaus Gerd Mohn, 1962, 69-74.

-, Eine ernstliche christeliche Erbietung. Balthasar Hubmaier Schriften. Edited by Gunnar Westin and Torsten Bergsten. Gütersloh, Germany: Gütersloher Verlagshaus Gerd Mohn, 1962, 75-84.

-, Axiomata-Schlußreden gegen Eck. Balthasar Hubmaier Schriften. Edited by Gunnar Westin and Torsten Bergsten. Gütersloh, Germany: Gütersloher Verlagshaus Gerd Mohn, 1962, 85-90.

-, Etliche Schlußreden vom Unterricht der Messe. Balthasar Hubmaier Schriften. Edited by Gunnar Westin and Torsten Bergsten. Gütersloh, Germany: Gütersloher Verlagshaus Gerd Mohn, 1962, 101-104.

-, Öffentliche Erbietung. Balthasar Hubmaier Schriften. Edited by Gunnar Westin and Torsten Bergsten. Gütersloh, Germany: Gütersloher Verlagshaus Gerd Mohn, 1962, 105-107.

-, Eine Summe eines ganzen christliche Lebens. Balthasar Hubmaier Schriften. Edited by Gunnar Westin and Torsten Bergsten. Gütersloh, Germany: Gütersloher Verlagshaus Gerd Mohn, 1962, 108-115.

-, Von der christlichen Taufe der Gläubigen. Balthasar Hubmaier Schriften. Edited by Gunnar Westin and Torsten Bergsten. Gütersloh, Germany: Gütersloher Verlagshaus Gerd Mohn, 1962, 116-163.

-, Die zwölf Artikel des christlichen Glaubens. Balthasar Hubmaier Schriften. Edited by Gunnar Westin and Torsten Bergsten. Gütersloh, Germany: Gütersloher Verlagshaus Gerd Mohn, 1962, 215-220.

-, Ein kurzes Vaterunser. Balthasar Hubmaier Schriften. Edited by Gunnar Westin and Torsten Bergsten. Gütersloh, Germany: Gütersloher Verlagshaus Gerd Mohn, 1962, 221-223.

-, Der uralten und gar neuen Lehrer Urteil. Ausgabe 1 und 2. Balthasar Hubmaier Schriften. Edited by Gunnar Westin and Torsten Bergsten. Gütersloh, Germany: Gütersloher Verlagshaus Gerd Mohn, 1962, 224-255.

-, Von der Kindertaufe. Balthasar Hubmaier Schriften. Edited by Gunnar Westin and Torsten Bergsten. Gütersloh, Germany: Gütersloher Verlagshaus Gerd Mohn, 1962, 256-269. 
-, Ein Entfältiger Unterricht. Balthasar Hubmaier Schriften. Edited by Gunnar Westin and Torsten Bergsten. Gütersloh, Germany: Gütersloher Verlagshaus Gerd Mohn, 1962, 77-84.

-, Eine Christliche Lehrtafel. Balthasar Hubmaier Schriften. Edited by Gunnar Westin and Torsten Bergsten. Gütersloh, Germany: Gütersloher Verlagshaus Gerd Mohn, 1962, 305-326.

-, Grund und Ursache. Balthasar Hubmaier Schriften. Edited by Gunnar Westin and Torsten Bergsten. Gütersloh, Germany: Gütersloher Verlagshaus Gerd Mohn, 1962, 327-336.

-, Von der brüderlichen Strafe. Balthasar Hubmaier Schriften. Edited by Gunnar Westin and Torsten Bergsten. Gütersloh, Germany: Gütersloher Verlagshaus Gerd Mohn, 1962, 337-346.

-, Eine Form zu Taufen. Balthasar Hubmaier Schriften. Edited by Gunnar Westin and Torsten Bergsten. Gütersloh, Germany: Gütersloher Verlagshaus Gerd Mohn, 1962, 347-352.

-, Eine Form des Nachtmahls Christi. Balthasar Hubmaier Schriften. Edited by Gunnar Westin and Torsten Bergsten. Gütersloh, Germany: Gütersloher Verlagshaus Gerd Mohn, 1962, 353-365.

-, Von dem christlichen Bann. Balthasar Hubmaier Schriften. Edited by Gunnar Westin and Torsten Bergsten. Gütersloh, Germany: Gütersloher Verlagshaus Gerd Mohn, 1962, 366-378.

-, Von der Freiheit des Willens. Balthasar Hubmaier Schriften. Edited by Gunnar Westin and Torsten Bergsten. Gütersloh, Germany: Gütersloher Verlagshaus Gerd Mohn, 1962, 379-397.

-, Das andere Büchlein von der Freiwilligkeit des Menschen. Balthasar Hubmaier Schriften. Edited by Gunnar Westin and Torsten Bergsten. Gütersloh, Germany: Gütersloher Verlagshaus Gerd Mohn, 1962, 398-431.

-, Von dem Schwert. Balthasar Hubmaier Schriften. Edited by Gunnar Westin and Torsten Bergsten. Gütersloh, Germany: Gütersloher Verlagshaus Gerd Mohn, 1962, 432-457.

-, Eine Rechenschaft des Glaubens. Balthasar Hubmaier Schriften. Edited by Gunnar Westin and Torsten Bergsten. Gütersloh, Germany: Gütersloher Verlagshaus Gerd Mohn, 1962, 458-492.

\section{Sekondêre Bronne}

Balke, W 1973. Calvijn en de Doperse Radikalen. Ton Bolland: Amsterdam.

Baron, R A \& Byrne, D 1996. Social Psychology. 8th. ed. Boston: Allyn \& Bacon.

Bender, Harold S 1944. The Anabaptist Vision. Herald Press, Scottdale.

Bergsten, T 1961. Balthasar Hubmaier: seine Stellung zu Reformation und Täufertum 1521-1528. Kassel: J G Oncken Verlag. 
Carrol, R P 1977. Ancient Israelite prophecy and dissonance theory, in NUMEN, International review for the history of religions, 135-151. Leiden: E J Brill.

Carrol, R P 1980. Prophecy and dissonance: A theoretical approach to the prophetic tradition. $Z A W 92,108-119$.

Festinger, L 1962. A Theory of Cognitive Dissonance. Stanford: Stanford University Press.

Hermann, R 1967. Luthers Theologie. Göttingen: Van den Hoeck \& Ruprecht.

Hillerbrand, Hans J 1964. The Reformation - a narative history related by cotemporary observers and participants. Harper and Row, Publishers. New York and Evaston.

Hillerbrand, Hans J 1968. The Protestant Reformation. Harper Torch-books: Harper \& Row, Publishers New York.

Hillerbrand, Hans J 1969. Men and Ideas in the Sixteenth Century. Rand McNally. College Publishing Company Chicago.

Hillerbrand, Hans J 1971. Theological Resources. Christendom divided- the Prostetant Reformation. Hutchinson of London. Corpus of New York.

Hillerbrand, Hans J 1986. Radical Tendencies in the Reformation: Divergent Perspectives. Edwards Brothers. Michigan.

Horsch, John 1920. Modern religious Liberalism. Garland Publishing, Inc. New York \& London.

Horsch, John 1927. The Principle of Nonresistance as held by the Mennonite Church. Scottdale, PA.

Horsch, John 1931. The Hutterian Brethern 1528-1931. Goshen, Indiana.

Horsch, John 1942. Mennonites in Europe. Herald Press: Scottdale, Pennsylvania, Kitchener, Ontario.

Jones, Tudur R 1985. The Great Reformation - a wide-ranging survey of the beginnings of Protestantism. Intervarsity Press, Downers Grove, Illinois.

Liland, P M I 1983. Anabaptist Separatism: A Historical and Theological Study of the Contribution of Balthasar Hubmaier (1485-1528). Boston College: U M I Dissertation Information Service

Lindeboom, J 1973. Stiefkinderen van het Christendom. Arnhem: Gijsbers \& Van Loon.

Mabry, Eddie 1994. Balthasar Hubmaier's Doctrine of the Church. University Press of America: Lanham, New York, London.

Müller, G 1986. Theologische Realenzyklopädie, Band 25. Walter de Gryter: Berlin, New York.

Pipkin, H W \& Yoder, J H 1989. Balthasar Hubmaier: Theologian of Anabaptism. Scottdale: Herald Press.

Sachsse, C 1914. D. Balthasar Hubmaier als Theologe. Aalen: Scientia Verlag.

Tesser, A 1995. Advanced Social Psycology. New York: McCraw-Hill, Inc. 
Westin, G \& Bergsten, T 1962. Balthasar Hubmaier: Schriften. Gütersloh: Verlagshaus Gerd Mohn.

Williams, G H 1946. The Radical Reformation. Philadelphia: The West-minster Press.

Windhorst, C 1976. Täuferisches Taufverständnis: Balthasar Hubmaiers Lehre zwischen traditioneller und reformatorischer Theologie. Leiden: E J Brill. 